\title{
Abundance and distribution of larval and juvenile fish in Coos Bay, Oregon: time-series analysis based on light-trap collections
}

\author{
Jessica A. Miller*, Alan L. Shanks \\ Oregon Institute of Marine Biology, University of Oregon, PO Box 5389, Charleston, Oregon 97420, USA
}

\begin{abstract}
Recent interest in the role of estuaries as 'essential fish habitat' has led to more precise definitions and quantitative assessments of estuaries as nursery habitat. Although the larvae and juveniles of $>20$ fish species are found in Pacific Northwest estuaries, information on their presence in and use of Oregon's estuaries is scarce. The objectives of this study were to use a long-term time series (3.75 yr) of high-frequency (every 1-2 d) light-trap collections from Coos Bay, Oregon to document species diversity, compare intra- and interannual patterns of species abundance and size, and identify potential wind- and/or tidally-driven transport mechanisms. Thirty-five taxa ( 28 species) of larval and juvenile fish were identified. Five species consistently comprised $>70 \%$ of the catch. On average, the majority ( $94 \pm 6 \% \mathrm{SD}$ ) of the catch at the most ocean-dominated site occurred during the downwelling season (1 October to 31 May) with 15 to $62 \%$ of that catch collected during the spring transition (1 April to 31 May) when conditions shift from predominantly downwelling to upwelling conditions. Conversely, $<1 \mathrm{~km}$ farther up estuary an average of $64 \pm 12.7 \% \mathrm{SD}$ of the catch occurred during downwelling conditions with only $8 \%$ during the spring transition. Relative abundance patterns indicate seasonal and spatial variation in estuarine use and potentially extended residence periods for some species. Time-series analyses indicate the presence of the larval and juvenile fish collected in the estuary may have been primarily regulated by a combination of tidally-driven transport and reproductive timing with less evidence for wind-driven transport.
\end{abstract}

KEY WORDS: Larval and juvenile fish · Temperate estuary $\cdot$ Light traps

\section{INTRODUCTION}

Numerous species of marine fish spend a portion of their lives, often as larvae or juveniles, within estuaries (Elliott \& Hemingway 2002). Some estuarine habitats, such as salt marsh and seagrass, play a vital role in the early life history of some fish species, and the presence of many other species in estuaries is well documented (Able \& Fahay 1998, Beck et al. 2001). The specific role, however, that estuaries play in species persistence is uncertain for many species. The current need for precise definitions of 'essential fish habitat' as prescribed in the 1996 Magnuson-Stevens Fishery Conservation and Management Act prompted Beck et al. (2001) to call on researchers to refine their definition of 'nursery habitat' and the experiments used to test the nursery function of estuaries, specifically in terms of density, growth, survival, and movement to adult habitats.

The larvae and juveniles of numerous fish species (>20) are found in Pacific Northwest estuaries (Haertel \& Osterberg 1967, Mistano 1977, Monaco et al. 1992). The region's estuaries, however, are considered less important in terms of fish production than other regions, such as the Gulf of Mexico and the southeastern United States (Pearcy \& Myers 1973, Haedrich 1983, Boehlert \& Mundy 1987). This is due, in part, to the less extensive estuarine area along the west coast of the United States. Conclusions regarding estuarine use, however, can be influenced by collection method. 
For example, Pearcy \& Myers (1973) concluded, after completing a planktonic survey that identified 44 types of larval fish in Yaquina Bay, Oregon, that the estuary appeared to function as a nursery only for Pacific herring Clupea pallasi and a variety of small cottids, gobies, and stichaeids. They note that their planktonic survey was not adequate to fully assess the estuary as a nursery due to their sample bias toward weakly swimming organisms in the water column. Strong swimmers, such as the surf perches (embiotocids), or benthic juveniles, such as the starry flounder Platichthys stellatus and English sole Parophrys vetulus, were not adequately sampled with plankton nets. Other research targeted larval and postlarval planktonic (Mistano 1977) or benthic fishes (Haertel \& Osterberg 1967, Bottom et al. 1987). Since the 1970s, most regional research has focused primarily on a few commercially important species, notably Pacific salmon Oncorhynchus spp. (Healey 1982, Fisher \& Pearcy 1990, Miller \& Sadro 2003) and P. vetulus (Boehlert \& Mundy 1987). The information available for most species is insufficient to estimate relative density, growth, or survival as suggested by Beck et al. (2001) or identify shifts in species composition, abundance, or habitat use.

The coastal environment off Oregon is characterized by seasonal variation in along- and cross-shore circulation patterns. During spring and summer, northwest winds result in persistent upwelling and the establishment of an upwelling front where low-density, offshore waters meet high-density, recently upwelled waters (Mooers et al. 1976). Late fall through early spring, winds are from the southwest, which promotes the shoreward movement and subsequent downwelling of surface waters. The spring transition, which is associated with an increase in the frequency and intensity of upwelling-favorable winds, typically occurs between mid-February and mid-May (Strub et al. 1987). The fall transition, which is less abrupt than the spring transition, typically occurs between September and October (Strub \& James 2000). Additionally, the predominant along-shore surface current over the continental shelf is equatorward during the upwelling period but reverses seasonally when the Davidson Current (Inshore Counter Current) moves shoreward and toward the surface during fall and winter (Huyer et al. 1979, Strub et al. 1987, Strub \& James 2000).

The apparent potential for larval loss in such a system due to advection away from adequate rearing and/or settlement areas contributed to Parrish et al.'s (1981) hypothesis that pelagic species should spawn primarily during downwelling to minimize such losses. Some pelagic species, however, reproduce and have eggs and larvae in coastal waters during summer upwelling, e.g. peak spawning for the northern sub- population of northern anchovy Engraulis mordax is July and August (Richardson 1981). Successful reproduction during the upwelling season has been proposed to result from an 'optimal window' in ocean conditions when intermediate wind speeds may enhance feeding efficiency and reduce larval loss (Lasker 1974, Cury \& Roy 1989). There are, however, relatively few data on the seasonal abundance patterns of larval and juvenile fish in Oregon's nearshore waters, and the mechanisms of transport are not well understood.

Pacific Northwest estuaries are relatively small, typically shallow, and strongly influenced by the coastal ocean. The physical and biological characteristics of the region's estuaries are tightly coupled with oceanic processes (Roegner \& Shanks 2001, Roegner et al. 2002, Miller \& Shanks 2004). Roegner et al. (2002) documented rapid $(<1 \mathrm{~d})$ exchange of estuarine waters after a wind reversal and the relaxation of upwelling. The estuarine intrusion of coastal waters resulted in a marked, prolonged ( $>5 \mathrm{~d}$ ) increase in phytoplankton standing stock (measured as fluorescence) within the estuary. It is not yet well described, however, how such tight ocean-estuary coupling affects secondary consumers, such as fish larvae, and their cross-shelf transport and estuarine ingress.

Larval and juvenile fish that reside in estuaries need to locate, enter, and potentially remain in such environments, whether by passive or active means (Boehlert \& Mundy 1988). Various wind- and tidally-driven transport mechanisms can promote shoreward movement (Shanks 1995, Epifanio \& Garvine 2001, Forward \& Tankersley 2001) and estuarine ingress (Boehlert \& Mundy 1988, Goodrich et al. 1989, Munch \& Conover 2000) of organisms. Estuarine ingress may be associated with onshore, or downwelling, winds that force coastal waters into the estuary (Goodrich et al. 1989, Munch \& Conover 2000). Non-linear internal tides and bores and tidal-stream transport through vertical migration can also promote shoreward transport and estuarine ingress (Kingsford \& Choat 1986, Pineda 1991, Shanks 1983, 1998). Additionally, modeling efforts have demonstrated the potential for net horizontal transport to occur in organisms that undergo diel vertical migration in oscillatory tidal currents over the continental shelf (Hill 1998). The relative importance of such mechanisms, however, to the shoreward transport and estuarine ingress of larval and juvenile fish in Pacific Northwest estuaries is not well described.

We previously completed a short-term (4 mo), highfrequency (every $2 \mathrm{~d}$ ) time-series analysis of light-trap collections to compare the timing and magnitude of abundance of juvenile fish and crab megalopae at a coastal and adjacent estuarine location and to identify potential transport mechanisms (Miller \& Shanks 
2004). Here we build upon that work with a study of larval and juvenile fish in the same temperate estuary, Coos Bay, Oregon, using a significantly longer time series (3.75 yr) of high-frequency (every 1 to $2 \mathrm{~d}$ ) lighttrap collections. The objectives of this study were to (1) document larval and juvenile fish species diversity (i.e. richness and abundance), (2) document intra- and interannual patterns in species abundance and size based on collections from 3 locations in the lower estuary, and (3) identify potential wind- and/or tidallydriven transport mechanisms. This study did not include any collections from the outer coast and did not aim to complete a comprehensive survey of larval and juvenile fish use of Coos Bay. Rather, the intent was to document seasonal and interannual patterns of larval and juvenile fish use at selected locations within Coos Bay and to identify potential wind- and/or tidallydriven transport mechanisms.

\section{MATERIALS AND METHODS}

Study site. The Coos Bay estuary is located on Oregon's south coast and, at ca. $54 \mathrm{~km}^{2}$, is the state's second largest estuary (Fig. 1). Tides are mixed, semidiurnal with a mean amplitude of $2 \mathrm{~m}$. The region experiences a distinct rainy season, from November to March, and the $30 \mathrm{yr}$ average annual precipitation is $161.3 \mathrm{~cm}$.

Biological sampling. Light traps were used to collect larval and juvenile fish. Traps (illustrated in Miller \&

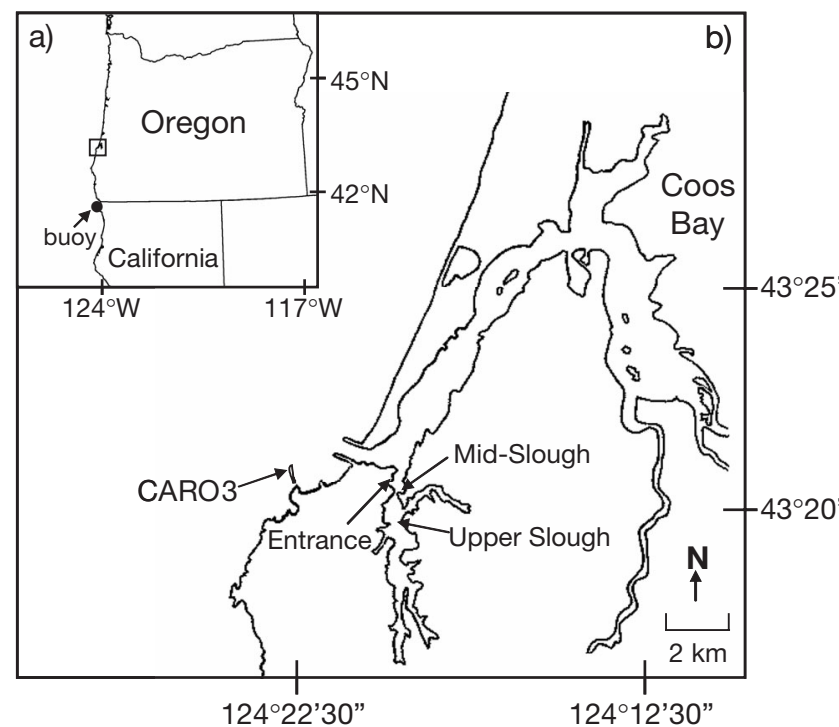

Fig. 1. Study sites in Coos Bay, Oregon. (a) Study region and (•)

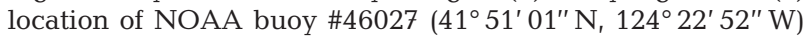
which provided surface water temperature data $(0.6 \mathrm{~m}$ water depth). (b) Map of Coos Bay indicating the location of Entrance, Mid-Slough, and Upper Slough light traps. NOAA's C-MAN Stn CAR03 ( $\left.43^{\circ} 20^{\prime} 30^{\prime \prime} \mathrm{N}, 124^{\circ} 22^{\prime} 30^{\prime \prime} \mathrm{W}\right)$, which provided daily wind speed and direction, is labeled
Shanks 2004) consisted of a 101 polycarbonate (clear) carboy with 10 circular funnel openings (diameter $=1$ to $1.25 \mathrm{~cm}$ ) and an $8 \mathrm{~W}$ fluorescent light in a sealed tube powered either by shore power or with a $12.0 \mathrm{~V}$, 12.0 Ah rechargeable $\mathrm{Pb}$-Acid acid battery controlled with a photocell. One light trap was deployed at the

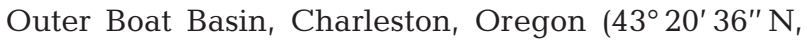
$\left.124^{\circ} 19^{\prime} 17^{\prime \prime} \mathrm{W}\right)$ from 1 April 1998 to 31 December 2001 (Fig. 1). Hereafter, this site is referred to as the Entrance. A set of 3 light traps was deployed at the Distant Fleet Facility $\left(43^{\circ} 20^{\prime} 12^{\prime \prime} \mathrm{N}, 124^{\circ} 19^{\prime} 14^{\prime \prime} \mathrm{W}\right)$, located ca. $1 \mathrm{~km}$ inside of Coos Bay, from 12 January 2000 to 31 December 2001. Hereafter, this site is referred to as Mid-Slough. Both of these sites were associated with a dock, and shore power was used. An additional set of 3 light traps was deployed farther up-estuary in

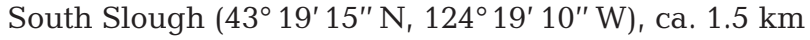
from the Entrance, from 9 June to 20 September 2001 (Fig. 1). Hereafter, this site is referred to as Upper Slough. These traps were tethered to anchored buoys and powered with $12.0 \mathrm{~V}$ batteries. Traps within each site were deployed 15 to $30 \mathrm{~m}$ apart and cleaned regularly. Dock traps were usually emptied once per day, while tethered traps were emptied every other day. Fish were identified to the lowest possible taxon, counted, and measured to the nearest $\mathrm{mm}$. Total length (TL) was used for preflexion fish and standard length (SL) for postflexion fish.

Although light traps are passive collectors of positively phototactic organisms, they offer advantages over more traditional net collections. Light traps allow for simultaneous and integrated sampling over a relatively long period, i.e. the entire night, which increases the probability of capture for rare organisms. They also often capture late-stage larvae and early juveniles, which are poorly sampled with nets (Milicich \& Doherty 1994). Therefore, this technique may be well suited to determine estuarine use by later-stage larvae and early juveniles (Strydom 2003). Additionally, these later stages may be more indicative of recruitment success than early larvae (Peterman et al. 1988).

Physical sampling. Hourly wind speed and direction were obtained from the National Oceanic and Atmospheric Administration's (NOAA) National Data Buoy Center's C-MAN Stn CAR03 $\left(43^{\circ} 20^{\prime} 30^{\prime \prime} \mathrm{N}\right.$, $124^{\circ} 22^{\prime} 30^{\prime \prime} \mathrm{W}$ ) located on the outer coast ca. $2 \mathrm{~km}$ south of Coos Bay (Fig. 1). Daily averages for alongshore and cross-shore wind stress $\left(\right.$ dyn $\left.\mathrm{cm}^{-2}\right)$ were calculated as described in Miller \& Shanks (2004). Daily average upwelling indices $\left(\mathrm{m}^{3} \mathrm{~s}^{-1}\right.$ per $100 \mathrm{~m}$ coastline) at $45^{\circ} \mathrm{N}, 125^{\circ} \mathrm{W}$ were obtained from the NOAA Pacific Fisheries Environmental Laboratory (PFEL), Pacific Grove, California (see Miller \& Shanks 2004 for details). Data on coastal ocean water temperatures $\left({ }^{\circ} \mathrm{C}\right)($ depth $=0.6 \mathrm{~m})$ were obtained from offshore 


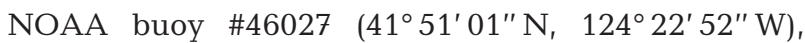
which was the closest working coastal buoy. Hourly surface water temperatures $\left({ }^{\circ} \mathrm{C}\right)$ were obtained from

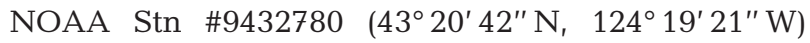
located in the Outer Boat Basin (Fig. 1). Additionally, water temperature and salinity for the Mid-Slough and the Upper Slough sites were obtained from the South Slough National Estuarine Research Reserve's System Wide Monitoring Program. Maximum daily tidal ranges $(\mathrm{cm})$ came from the Harbor Master software program.

Statistical analysis. Time-series analysis was used to compare catch between trap locations and identify potential transport mechanisms. A constant time step, or sample frequency, is necessary for time-series analysis. A daily time step was used for all analyses that did not include samples from the Upper Slough site, which were collected every other day. Biological and physical data were averaged over $2 \mathrm{~d}$ for analyses that included Upper Slough samples. Species abundance data were log-transformed to reduce the influence of large peaks and examined for trends and/or autocorrelations (Emery \& Thomson 1997).

The biological time series, due to the pulsed nature of the catch data, typically displayed a significant autocorrelation with an exponential decay. The autocorrelation can be removed by differencing the original data series with a smoothed data series to generate residuals (Miller \& Shanks 2004). If biological data displayed a significant autocorrelation, data were smoothed with an unweighted moving average (19 d average for all time series $>200 \mathrm{~d}$ in length and $9 \mathrm{~d}$ average for all time series $<200 \mathrm{~d}$ in length). The difference, or residual, between the data series and the smoothed data was computed with Eq. (1):

$$
X_{t}=Y_{t}-Z_{t}
$$

where $X_{t}=$ residual at time $t, Y_{t}=$ raw data at time $t$, and $Z_{t}=$ smoothed data at time $t$. The residuals were then smoothed with a $3 \mathrm{~d}$ moving average to remove high-frequency noise. We considered the above transformation successful if the exponential decay in the autocorrelation function associated with the biological series was removed.

If a physical data series displayed a seasonal trend, the trend was removed. Trends were evaluated with linear regression. If a series displayed a significant linear trend $(\mathrm{p} \leq 0.05)$, the trend was removed with Eq. (2):

$$
\mathrm{X}_{d}=\mathrm{X}_{i}-(a+b \times t)
$$

where $\mathrm{X}_{d}=$ detrended value at time $t, \mathrm{X}_{i}=$ original value at time $t, a$ (intercept) and $b$ (slope) are computed from the original data series via least squares regression, and $t=$ time, i.e. sample day. The trend removal was considered successful if there was no longer a significant linear regression in the series. The upwelling indices, however, were an exception. The annual pattern of daily average upwelling was curvilinear (i.e. concave) due to largely positive values during spring and summer months. Therefore, a residual analysis as described above for the biological series was used on the time series of daily average upwelling indices.

Biological time series were statistically compared with physical variables indicative of wind and tidal conditions, including surface water temperature, salinity, along-shore and cross-shore wind stress, upwelling index, and maximum daily tidal range. This allowed identification of potential transport mechanisms. Timeseries analysis measures the strength of a relationship between 2 variables. As in all correlative studies, a significant statistical correlation does not necessarily imply a cause-and-effect relationship. In this study, lags between variables represent days; the sign indicates whether peaks in the lagged series occurred after (negative values) or before (positive values) changes in the other variable. Positive along-shore wind stress crosscorrelatations indicate a relationship with northward winds, and negative along-shore wind stress crosscorrelations indicate southward winds. Positive crossshore wind stress cross-correlations indicate a relationship with eastward, and negative cross-shore wind stress cross-correlations indicate westward winds. Positive maximum tidal range cross-correlations indicate a relationship with spring tides, and negative maximum tidal range cross-correlations indicate neap tides. Timeseries analyses of fish abundance and physical variables were completed only when adequate numbers of fish (>50 individuals $\mathrm{yr}^{-1}$ ) were collected. Statistica was used for all time-series analyses.

Annual patterns. Annual patterns in fish abundance were examined in 2 ways. First, annual catch was divided into periods dominated by either upwelling or downwelling conditions to determine how catch varied during these periods. Years were divided into (1) winter downwelling to spring transition, (2) upwelling, and (3) fall transition to downwelling. Due to the variation in the timing of the spring transition, 2 dates, 1 April and 1 June, were used for the onset of upwelling. Therefore, the periods examined were (1) 1 January to 31 March (winter downwelling), (2) 1 January to 31 May (extended winter downwelling), (3) 1 April to 30 September (extended upwelling), (4) 1 June to 30 September (upwelling), and (5) 1 October to 31 December (fall downwelling). Second, single-spectrum Fourier analysis was used to test for significant cycles in the abundance of the most common species collected. This analysis was limited to the 3 complete years of data collection, 1999 to 2001, at the Entrance site, and STATISTICA was used. 
Fish size. An average daily fish size (mm, SL) for each year was calculated for the most common species collected. For each day a species was collected at a site, all individuals were pooled to generate a daily average size, e.g. all fish caught in the one Entrance trap or the 3 Mid-Slough traps. The daily averages were used to generate an annual average for each species at each site. The daily averages displayed discontinuous and non-normal distributions. Therefore, nonparametric statistics were used to test for differences between collection sites. However, the assumptions of equal population dispersion and similar distributional shape were frequently not met and could not be corrected with data transformations. Therefore, MannWhitney $U$ tests were used to test for differences between collection sites only when fish size distributions were similar among locations.

\section{RESULTS}

Overall, 28 species of larval, primarily postflexion, and juvenile fish were identified in all samples combined. Seven additional and unique species of larvae or juveniles were identified to genus. Adult sand lance Ammodytes hexapterus, stickleback Gasterosteus acculeatus, and bay pipefish Syngnathus leptorhynchus were also collected but will not be discussed further. Twenty-three species of larvae or juveniles were identified at the Entrance (Table 1), 22 at MidSlough (Table 2), and 3 at Upper Slough (Table 3).

The majority of the species collected are demersal spawners with attached, adhesive, or guarded eggs. The exceptions include the pelagic spawners, e.g. northern anchovy Engraulis mordax, Pacific sardine Sardinops sagax, and English sole Parophrys vetulus, and live bearers, e.g. the rockfishes Sebastes spp. The Sebastes spp. identified in this study (Tables 1 \& 2) comprised at least 4 species, including black $S$. melanops, brown $S$. auriculatus, and yellowtail $S$. flavidus rockfish.

Five species consistently comprised the majority $(>70 \%)$ of the catch, including northern anchovy Engraulis mordax, penpoint gunnel Apodichthys flavidus, Pacific sardine Sardinops sagax, rosylip sculpin Ascelichthys rhodorus, and surf smelt Hypomesus pretiosus. Correlations of species catch between traps within a site averaged $+0.55 \pm 0.10 \mathrm{SD}$ and ranged from +0.40 to +0.62 .

Table 1. Taxa collected in light traps at Entrance site, Coos Bay, Oregon in 1998, 1999, 2000, and 2001. n: number of individuals collected; \%: percent of total

\begin{tabular}{|c|c|c|c|c|c|c|c|c|c|}
\hline \multirow[t]{2}{*}{ Species } & \multirow{2}{*}{ Common name } & \multicolumn{2}{|c|}{1998} & \multicolumn{2}{|c|}{1999} & \multicolumn{2}{|c|}{2000} & \multicolumn{2}{|c|}{2001} \\
\hline & & $\mathrm{n}$ & $\%$ & $\mathrm{n}$ & $\%$ & $\mathrm{n}$ & $\%$ & $\mathrm{n}$ & $\%$ \\
\hline Engraulis mordax & Northern anchovy & 122 & 21.3 & 23 & 2.2 & 117 & 29.4 & 43 & 6.6 \\
\hline Apodichthys flavidus & Penpoint gunnel & 140 & 24.4 & 578 & 55 & 83 & 20.9 & 150 & 23.2 \\
\hline Sardinops sagax & Pacific sardine & 163 & 28.4 & 15 & 1.4 & 9 & 2.3 & 43 & 6.6 \\
\hline Ascelichthys rhodorus & Rosylip sculpin & 76 & 13.2 & 241 & 22.9 & 52 & 13.1 & 145 & 22.4 \\
\hline Hypomesus pretiosus & Surf smelt & 11 & 1.9 & 26 & 2.5 & 58 & 14.6 & 110 & 17 \\
\hline Sebastes spp. & Rockfish & 17 & 3.0 & 94 & 8.9 & 5 & 1.3 & 5 & $<1$ \\
\hline Clinocottus globiceps & Mosshead sculpin & 14 & 2.4 & 0 & 0 & 6 & 1.5 & 0 & 0 \\
\hline Leptocottus armatus & Staghorn sculpin & 13 & 2.3 & 9 & $<1$ & 14 & 3.5 & 1 & $<1$ \\
\hline Clupea pallasi & Pacific herring & 11 & 1.9 & 1 & $<1$ & 0 & 0 & 0 & 0 \\
\hline Clinocottus acuticeps & Sharpnose sculpin & 4 & $<1$ & 18 & 1.7 & 8 & 2.0 & 10 & 1.5 \\
\hline Pholis laeta/ornata & Gunnel & 1 & $<1$ & 17 & 1.6 & 11 & 2.8 & 39 & 6.0 \\
\hline Artedius lateralis & Smoothhead sculpin & 1 & $<1$ & 0 & 0 & 0 & 0 & 0 & 0 \\
\hline Artedius sp. & Sculpin & 0 & 0 & 0 & 0 & 5 & 1.3 & 1 & $<1$ \\
\hline Atherinops affinis & Top smelt & 0 & 0 & 0 & 0 & 1 & $<1$ & 0 & 0 \\
\hline Aulorhynchus flavidus & Tubesnout & 0 & 0 & 1 & $<1$ & 0 & 0 & 0 & 0 \\
\hline Clinocottus embryum & Calico sculpin & 0 & 0 & 6 & 0.6 & 0 & 0 & 1 & $<1$ \\
\hline Cottus sp. & Sculpin & 0 & 0 & 0 & 0 & 11 & 2.8 & 0 & 0 \\
\hline Enophyrs bison & Buffalo scuplin & 0 & 0 & 1 & $<1$ & 0 & 0 & 0 & 0 \\
\hline Hemilepidotus sp. & Irish lord & 0 & 0 & 0 & 0 & 0 & 0 & 1 & $<1$ \\
\hline Lepidopsetta bilineata & Rock sole & 0 & 0 & 0 & 0 & 0 & 0 & 9 & 1.4 \\
\hline Liparis sp. & Snailfish & 0 & 0 & 14 & 1.3 & 5 & 1.3 & 4 & $<1$ \\
\hline Oligocottus sp. & Sculpin & 0 & 0 & 0 & 0 & 1 & $<1$ & 0 & 0 \\
\hline Ophiodon elongatus & Lingcod & 0 & 0 & 0 & 0 & 5 & 1.3 & 0 & 0 \\
\hline Parophrys vetulus & English sole & 0 & 0 & 0 & 0 & 0 & 0 & 7 & 1.1 \\
\hline Pholis schultzi & Red gunnel & 0 & 0 & 0 & 0 & 1 & $<1$ & 0 & 0 \\
\hline Ronquilus jordani & Ronquil & 0 & 0 & 1 & $<1$ & 0 & 0 & 0 & 0 \\
\hline Scorpaenichthys marmoratus & Cabezon & 0 & 0 & 0 & 0 & 1 & $<1$ & 40 & 6.2 \\
\hline Total & & 573 & 100 & 1045 & 100 & 393 & 100 & 609 & 100 \\
\hline
\end{tabular}


Table 2. Taxa collected in light traps at Mid-Slough site in Coos Bay, Oregon in 2000 and 2001. n: number of individuals collected; $\%$ : percent of total; mean: average number of individuals collected per trap

\begin{tabular}{|c|c|c|c|c|c|c|c|}
\hline \multirow[t]{2}{*}{ Species } & \multirow[t]{2}{*}{ Common name } & \multicolumn{3}{|c|}{2000} & \multicolumn{3}{|c|}{2001} \\
\hline & & $\mathrm{n}$ & $\%$ & Mean & $\mathrm{n}$ & $\%$ & Mean \\
\hline Engraulis mordax & Northern anchovy & 1128 & 61.7 & 376 & 845 & 42.1 & 281.7 \\
\hline Apodichthys flavidus & Penpoint gunnel & 52 & 2.8 & 17.3 & 70 & 3.5 & 23.3 \\
\hline Sardinops sagax & Pacific sardine & 108 & 5.9 & 36.0 & 519 & 25.9 & 173.0 \\
\hline Ascelichthys rhodorus & Rosylip sculpin & 26 & 1.4 & 8.7 & 12 & $<1$ & 4.0 \\
\hline Hypomesus pretiosus & Surf smelt & 80 & 4.4 & 26.7 & 216 & 10.8 & 72.0 \\
\hline Sebastes spp. & Rockfish & 32 & 1.7 & 10.7 & 51 & 2.5 & 17.0 \\
\hline Clinocottus globiceps & Mosshead sculpin & 1 & $<1$ & 0.3 & 2 & $<1$ & 0.7 \\
\hline Leptocottus armatus & Staghorn sculpin & 6 & $<1$ & 2.0 & 0 & 0 & 0 \\
\hline Clupea pallasi & Pacific herring & 2 & $<1$ & 0.7 & 7 & $<1$ & 2.3 \\
\hline Clinocottus acuticeps & Sharpnose sculpin & 64 & 3.5 & 21.3 & 113 & 5.6 & 37.7 \\
\hline Pholis laeta/ornata & Gunnel & 24 & 1.3 & 8.0 & 1 & $<1$ & 0.3 \\
\hline Anoplarchus purpurescens & High cockscomb & 1 & $<1$ & 0.3 & 0 & 0 & 0 \\
\hline Artedius sp. & Sculpin & 7 & $<1$ & 2.3 & 0 & 0 & 0 \\
\hline Atherinops affinis & Top smelt & 4 & $<1$ & 1.3 & 3 & $<1$ & 1.0 \\
\hline Aulorhynchus flavidus & Tubesnout & 0 & 0 & 0 & 2 & $<1$ & 0.7 \\
\hline Clinocottus embryum & Calico sculpin & 13 & $<1$ & 4.3 & 2 & $<1$ & 0.7 \\
\hline Clinocottus recalvus & Bald sculpin & 1 & $<1$ & 0.3 & 0 & 0 & 0 \\
\hline Hemilepidotus sp. & Irish lord & 0 & 0 & 0 & 2 & $<1$ & 0.7 \\
\hline Lepidopsetta bilineata & Rock sole & 0 & 0 & 0 & 8 & $<1$ & 2.7 \\
\hline Liparis sp. & Snailfish & 3 & $<1$ & 1.0 & 5 & $<1$ & 1.7 \\
\hline Oligocottus maculosus & Tidepool sculpin & 2 & $<1$ & 0.7 & 0 & 0 & 0 \\
\hline Oligocottus snyderi & Fluffy scuplin & 6 & $<1$ & 2.0 & 0 & 0 & 0 \\
\hline Oligocottus sp. & Sculpin & 5 & $<1$ & 1.7 & 0 & 0 & 0 \\
\hline Ophiodon elongatus & Lingcod & 0 & 0 & 0 & 13 & $<1$ & 4.3 \\
\hline Ronquilus jordani & Ronquil & 1 & $<1$ & 0.3 & 0 & 0 & 0 \\
\hline Total & & 1566 & 100 & & 1871 & 100 & \\
\hline
\end{tabular}

Table 3. Taxa collected in light traps at Upper Slough site, Coos Bay, Oregon in 2001. n: number of individuals collected; $\%$ : percent of total; mean: average number of individuals collected per trap

\begin{tabular}{|lcrcc|}
\hline Species & Common name & $\mathrm{n}$ & $\%$ & Mean \\
\hline Engraulis mordax & Northern anchovy & 158 & 72.8 & 52.7 \\
Hypomesus pretiosus & Surf smelt & 58 & 26.7 & 19.3 \\
Pholis ornata & Saddleback gunnel & 1 & $<1$ & 0.3 \\
Total & & 217 & 100 & \\
\hline
\end{tabular}

Northern anchovy Engraulis mordax spawn throughout the year in California, but spawning appears to be concentrated in summer months farther north (Richardson 1981). Three subpopulations of E. mordax have been identified, namely northern (British Columbia to northern California), central (off southern California and northern Baja California), and southern (off central and southern Baja California) (Kucas 1986). Pacific sardine Sardinops sagax spawn in central California from January to June and typically migrate northward during summer. Surf smelt Hypomesus pretiosus are reported to spawn throughout the year in much of their range with peaks in spring and summer months (Love 1996). Rosylip sculpin Ascelichthys rhodorus have a relatively brief, seasonal spawning peak, reportedly from early January to early February in Puget Sound (Petersen et al. 2004). Penpoint gunnel Apodichthys flavidus spawn from January to March.

\section{Entrance}

In 1998, 15 unique taxa were collected at the Entrance and 13 identified to species (Table 1). In 1999, 18 unique taxa were collected and 15 identified to species. In 2000, 20 unique taxa were collected and 15 identified to species. In 2001, 18 unique taxa were collected and 14 identified to species.

\section{Mid-Slough}

In 2000, 23 unique taxa were collected at the MidSlough site and 19 identified to species (Table 2). In 2001, 19 unique taxa were collected and 16 identified to species.

\section{Upper Slough}

Three species were collected at the Upper Slough site in 2001, the only year that light traps were main- 
tained at this location (Table 3). Northern anchovy Engraulis mordax and surf smelt Hypomesus pretiosus comprised $99.5 \%$ of the total catch.

\section{Annual patterns}

The majority of the Entrance catch (60\%) occurred between 1 October and 31 March, the downwelling season (Fig. 2). A variable but significant portion of the catch (15 to $63 \%$ ), however, occurred during April and May, a period that includes the spring transition (Table 4). At Mid-Slough, an average of $56 \%$ of the catch occurred during the downwelling season, with only $8 \%$ during the spring transitional period. Additionally, an average of $40 \%$ of the catch at Mid-Slough occurred during the fall portion of the downwelling season (1 October to 31 December) compared with only $14 \%$ at the Entrance (Table 4). Overall, distinct differences in species abundance were observed at these 2 sites located in relatively close proximity.

Further discussion on abundance patterns will be limited to the 5 species that consistently comprised $>70 \%$ of the total catch, which includes northern anchovy Engraulis mordax, penpoint gunnel Apodichthys flavidus, Pacific sardine Sardinops sagax, rosylip sculpin Ascelichthys rhodorus, and surf smelt Hypomesus pretiosus.

Consistent annual cycles were observed in the abundance of penpoint gunnel Apodichthys flavidus and rosylip sculpin Ascelichthys rhodorus (Fig. 3) that were not observed in the other species (Fig. 4).
Fourier analysis generated periodogram values that represented the variance in the data associated with a specific period. A. flavidus and A. rhodorus displayed a significant cycle in their catch over a $365 \mathrm{~d}$ period with periodogram values of 6.7 and 2.7 , respectively.

The initial arrival date and duration a species was collected in light traps were determined for the 5 dominant species. Average values for the Entrance site were based on collections from 1999 to 2001 and for Mid-Slough from 2000 to 2001. Penpoint gunnel Apodichthys flavidus first appeared at the Entrance on 17 February $( \pm 11 \mathrm{~d}$ SD) and were collected for $100 \pm$ 24 d (Fig. 3a). A. flavidus first appeared at Mid-Slough on 9 March $( \pm 11 \mathrm{~d}$ SD) and were collected for $114 \pm 11$ d. Rosylip sculpin Ascelichthys rhodorus first appeared at the Entrance on 16 January $( \pm 14$ d SD) and were collected for $83 \pm 41 \mathrm{~d}$ (Fig. 3b). At MidSlough, A. rhodorus first appeared on 13 Januray in both 2000 and 2001 and were collected an average of $73 \pm 7 \mathrm{~d}$. Northern anchovy Engraulis mordax, Pacific sardine Sardinops sagax, and surf smelt Hypomesus pretiosus were frequently collected in January and were often present during the year, except for 1999, when very few individuals of these 3 species were collected (Fig. 4).

\section{Interannual abundance}

Interannual patterns in species abundance were examined at the Entrance from 1998 to 2001 and Mid-Slough from 2000 to 2001. Although the species collected were similar among years at the Entrance site, markedly larger catches
Fig. 2. Daily catch $\left(\log _{10}\right)$ of larval and juvenile fish collected in light traps at Entrance site between 1 April 1998 and 31 December 2001. Fish abundance and daily average upwelling indices were smoothed with a $19 \mathrm{~d}$ moving average. Upwelling is typically indicated by values above $100 \mathrm{~m}^{3} \mathrm{~s}^{-1}$. Downwelling periods, 1 October through 31 March, are shown by shaded areas

Table 4. Percent frequency of occurrence for larval and juvenile fish collected in
light traps in Coos Bay, Oregon in 1999, 2000, and 2001. Data from Entrance and Mid-Slough are presented. The year is divided into periods dominated by

\begin{tabular}{lccccc|}
\hline & \multicolumn{3}{c}{ Entrance } & \multicolumn{3}{c|}{ Mid-Slough } \\
& 1999 & 2000 & 2001 & 2000 & 2001 \\
\hline Downwelling dominated & 21 & 57 & 58 & 18 & 14 \\
$\begin{array}{l}\text { 1 Jan-31 Mar } \\
\text { 1 Jan-31 May }\end{array}$ & 84 & 81 & 73 & 26 & 22 \\
Spring transition & 63 & 24 & 15 & 8 & 8 \\
$\begin{array}{l}\text { 1 Apr-31 May } \\
\text { Upwelling dominated }\end{array}$ & 76 & 27 & 19 & 35 & 53 \\
$\begin{array}{l}\text { 1 Apr-30 Sep } \\
\text { 1 Jun-30 Sep } \\
\text { Downwelling dominated }\end{array}$ & 13 & 2 & 4 & 27 & 45 \\
1 Oct-31 Dec & 3 & 16 & 23 & 47 & 33 \\
\hline
\end{tabular}

. 

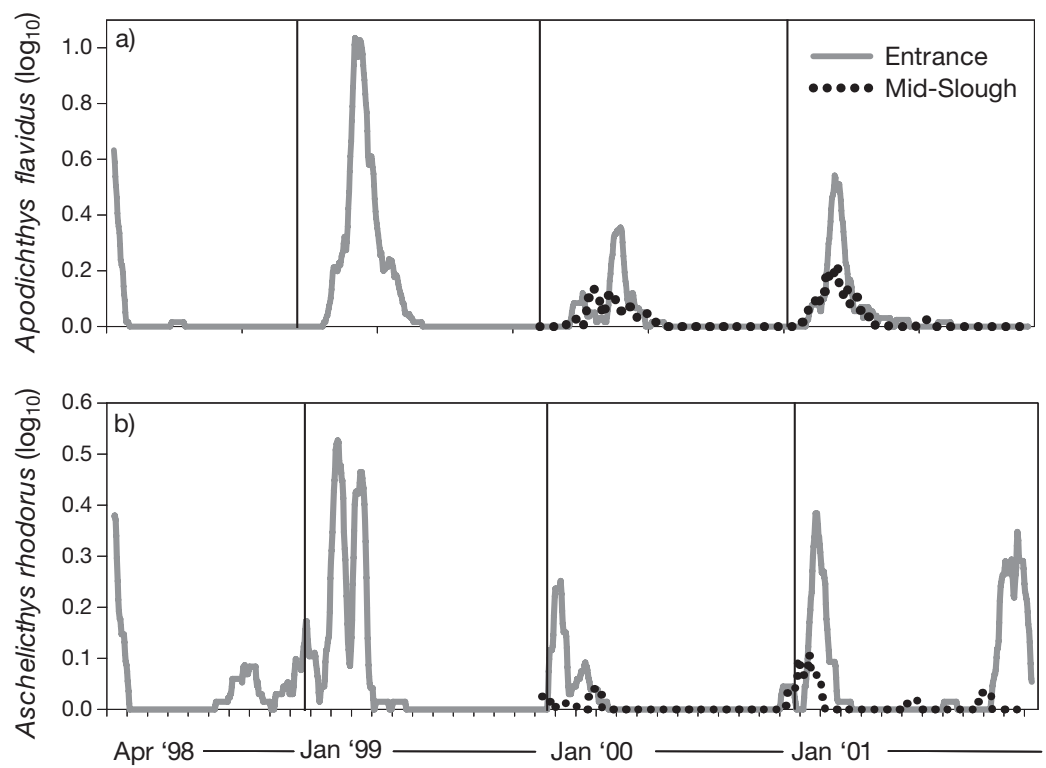

Fig. 3. Apodichthys flavidus and Ascelichthys rhodorus. Daily catch $\left(\log _{10}\right)$ of (a) penpoint gunnel A. flavidus and (b) rosylip sculpin A. rhodorus collected between 1 April 1998 and 31 December 2001. Data were smoothed with a $19 \mathrm{~d}$ moving average
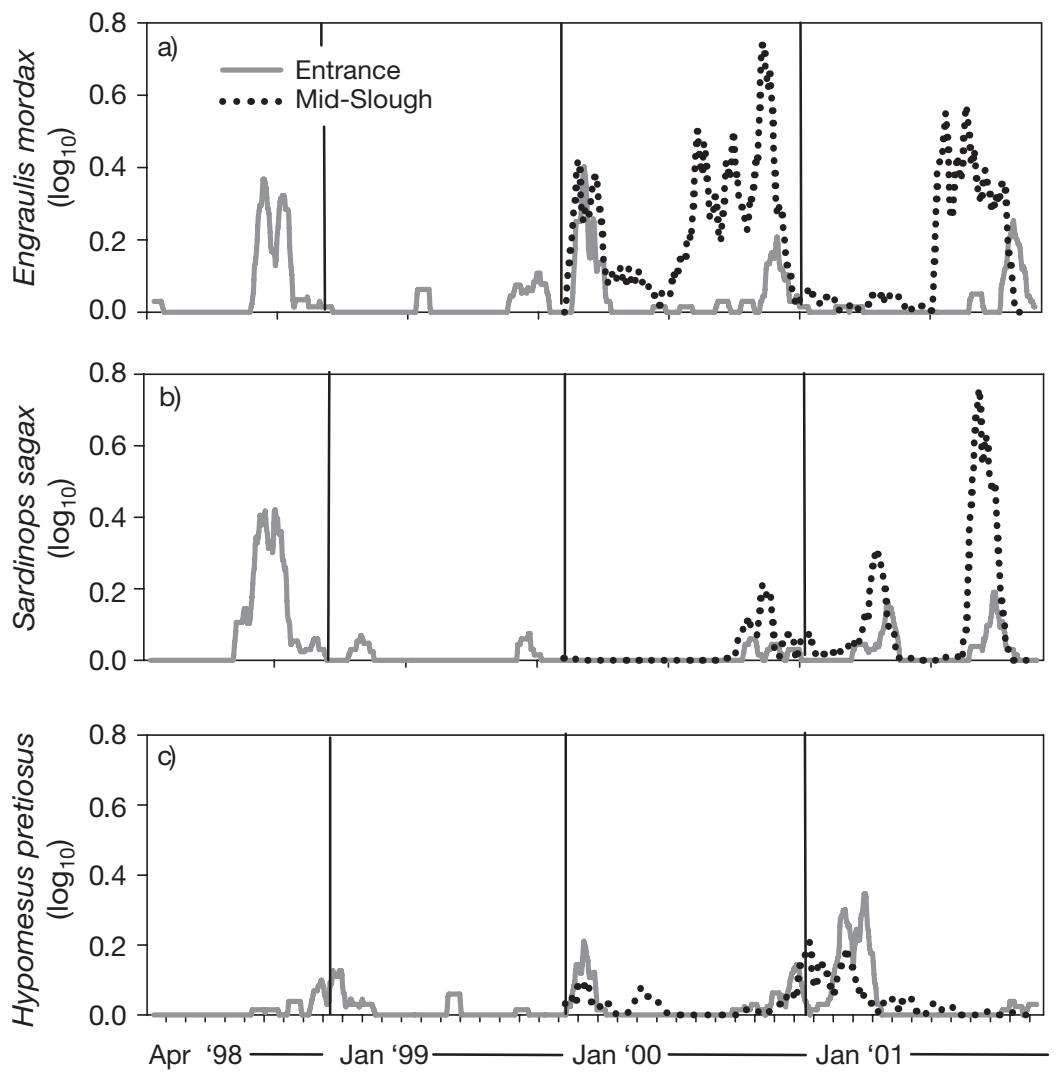

Fig. 4. Engraulis mordax, Sardinops sagax and Hypomesus pretiosus. Daily catch $\left(\log _{10}\right)$ of (a) northern anchovy E. mordax, (b) Pacific sardine S. sagax, and (c) surf smelt $H$. pretiosus collected between 1 April 1998 and 31 December 2001. Data were smoothed with a 19 d moving average of the demersal spawners Ascelichthys rhodorus (241) and Apodichthys flavidus (578) and the viviparous Sebastes spp. (94) occurred in 1999 (Table 1). This coincided with reduced catches of the pelagic spawners Engraulis mordax (23) and Sardinops sagax (15). At MidSlough, species composition and relative abundance were similar in 2000 and 2001, except for notably larger catches of S. sagax and Hypomesus pretiosus in 2001 (Table 2).

\section{Relative site abundance}

In 2000 and 2001, 4 species - northern anchovy Engraulis mordax, Pacific sardine Sardinops sagax, surf smelt Hypomesus pretiosus, and penpoint gunnel Apodichthys flavidus-were collected in adequate numbers at the Entrance and Mid-Slough to compare the relative timing of their abundance. Due to the relatively limited catch at Upper Slough, no statistical comparisons were made with that site.

In 2000, peaks in the abundance of Engraulis mordax, Sardinops sagax, and Hypomesus pretiosus at MidSlough were positively cross-correlated with abundance at the Entrance. Peaks in abundance at Mid-Slough occurred on the same day or $1 \mathrm{~d}$ after peaks in abundance at the Entrance ( 0 to $-1 \mathrm{~d}$ lags, $r=+0.301$ to +0.474 ). For $S$. sagax, however, peaks in abundance at MidSlough also occurred $1 \mathrm{~d}$ before the Entrance (+1 d lag, $r=+0.491)$. For Apodichthys flavidus, peaks in abundance at Mid-Slough occurred $2 \mathrm{~d}$ after peaks in abundance at the Entrance site $(\mathrm{r}=+0.200)$.

In 2001, peaks in abundance of Engraulis mordax and Sardinops sagax at Mid-Slough tended to occur on the same day or $1 \mathrm{~d}$ after peaks in abundance at the Entrance ( 0 to $-1 \mathrm{~d}$ lags, $\mathrm{r}=$ +0.212 to +0.256 ). For $S$. sagax, however, peaks in abundance at MidSlough also occurred $1 \mathrm{~d}$ before the Entrance (+1 d lag, $\mathrm{r}=+0.322)$. For Apodichthys flavidus, peaks at MidSlough occurred $3 \mathrm{~d}$ after peaks in abundance at the Entrance $(r=+0.246)$. 


\section{Fish size}

In general, there was little interannual variation in the daily average size of the dominant species collected at the Entrance (Table 5). The trend for Sardinops sagax, however, was that fish were progressively larger each year of collection. The assumption of similar statistical distributions required for the Mann-Whitney U test was not met in all cases. Thus, statistical comparisons between collection sites were made only when fish size distributions were similar among locations, i.e. between Hypomesus pretiosus, Apodichthys flavidus, and Ascelicthys rhodorus at the Entrance and Mid-Slough in 2000. There was no statistically significant difference in the daily average size of $H$. pretiosus between the 2 sites in 2000 ( $Z=$ $-1.9 ; \mathrm{p}=0.06)$. In 2001, however, H. pretiosus were larger (50.7 \pm 13.1) at Mid-Slough than at the Entrance (32.1 \pm 12.4) (Table 5). A. flavidus were larger at Mid-Slough than at the Entrance in 2000 $(Z=-2.8 ; \mathrm{p}=0.008)$ and 2001 (Table 5). There were no statistically significant differences in A. rhodorus size in $2000(U=-0.9 ; \mathrm{p}=0.37)$, and daily average sizes were similar in 2001. Daily average size of Engraulis mordax and $S$. sagax were similar at all sites in 2000 and 2001.

Adequate numbers of Engraulis mordax were collected at Mid-Slough in 2000 and 2001 to examine size distributions throughout the year (Fig. 5). In 2000, catch occurred predominantly at the beginning and at the end of the year (Fig. 5a-c). The smallest fish (21 to $33 \mathrm{~mm}$ SL) comprised relatively small but consistent proportions of the catch. In contrast, in 2001, very few E. mordax were collected at the beginning of the year, and there was a major peak in catch in August and September with comparatively few larger juveniles (41 to $50 \mathrm{~mm} \mathrm{SL}$ ) (Fig. $5 \mathrm{~d}-\mathrm{e}$ ).

\section{Potential transport mechanisms}

Fig. 6 presents the physical variables observed during the study. Water temperature at the Coos Bay entrance was significantly and positively correlated with the offshore station at 0 to $-2 \mathrm{~d}$ lags $(\mathrm{r}=+0.253$ to +0.421$)$. Water temperatures farther up-estuary were often warmer than offshore waters, particularly during spring. Crosscorrelations between physical variables and fish catch are presented in Table 6 ; no data on temperature or salinity are presented because no significant correlations between those variables and fish catch were observed.

\section{Northern anchovy Engraulis mordax}

The abundance of Engraulis mordax displayed a significant tidal periodicity in catch in 2000 and 2001. In 2000, E. mordax abundance was significantly cross-correlated with spring tides at the Entrance ( 2 to $3 \mathrm{~d}$ lags) and at Mid-Slough (1 to 3 d lags) (Table 6). In 2001, significant cross-correlations indicated that peak catches tended to occur in between spring and neap tides at Mid-Slough and around neap tides at Upper Slough. There were also significant positive relationships between E. mordax abundance at the Entrance and positive along-shore wind stress (downwelling favorable) and negative upwelling indices in 1998, and negative upwelling indices in 2000 (Table 6). Time-series analyses were not performed on data from the Entrance in 1999 and 2001 due to the small number of E. mordax collected (i.e. <50).

\section{Pacific sardine Sardinops sagax}

The abundance of Sardinops sagax displayed a significant tidal periodicity in catch in 1998, 2000, and

Table 5. Standard length $(\mathrm{mm})$ of 5 most abundant species collected in Coos Bay light traps; data are means \pm SD. Collections from Entrance 1998 to 2001, Mid-Slough 2000 and 2001, and Upper Slough 2001 are presented. The sample size (n), i.e. number of days, is included. na: species not collected

\begin{tabular}{|c|c|c|c|c|c|c|c|}
\hline \multirow[t]{2}{*}{ Species } & \multicolumn{4}{|c|}{ Entrance } & \multicolumn{2}{|c|}{ Mid-Slough } & \multirow{2}{*}{$\begin{array}{c}\text { Upper Slough } \\
2001\end{array}$} \\
\hline & 1998 & 1999 & 2000 & 2001 & 2000 & 2001 & \\
\hline $\begin{array}{l}\text { Northern anchovy } \\
\text { (Engraulis mordax) }\end{array}$ & $\begin{array}{l}35.3 \pm 7.7 \\
\quad(16)\end{array}$ & $\begin{array}{l}35.4 \pm 5.1 \\
\quad(13)\end{array}$ & $\begin{array}{c}39.5 \pm 11.8 \\
(31)\end{array}$ & $\begin{array}{c}39.3 \pm 11.5 \\
(3)\end{array}$ & $\begin{array}{l}41.8 \pm 10.9 \\
\quad(141)\end{array}$ & $\begin{array}{c}43.6 \pm 17.6 \\
(67)\end{array}$ & $\begin{array}{c}39.3 \pm 14.0 \\
(19)\end{array}$ \\
\hline $\begin{array}{l}\text { Pacific sardine } \\
\text { (Sardinops sagax) }\end{array}$ & $\begin{array}{l}36.7 \pm 7.8 \\
(19)\end{array}$ & $\begin{array}{c}42.5 \pm 10.9 \\
\text { (3) }\end{array}$ & $\begin{array}{l}56.4 \pm 6.3 \\
\quad(9)\end{array}$ & $\begin{array}{c}65.9 \pm 14.8 \\
(19)\end{array}$ & $\begin{array}{l}56.0 \pm 19.5 \\
(32)\end{array}$ & $\begin{array}{c}61.3 \pm 16.2 \\
(70)\end{array}$ & na \\
\hline $\begin{array}{l}\text { Surf smelt } \\
\text { (Hypomesus pretiosus) }\end{array}$ & $\begin{array}{c}34.6 \pm 5.2 \\
\quad(4)\end{array}$ & $\begin{array}{l}42.3 \pm 4.0 \\
\quad(7)\end{array}$ & $\begin{array}{l}33.6 \pm 6.1 \\
(25)\end{array}$ & $\begin{array}{c}32.1 \pm 12.4 \\
(23)\end{array}$ & $\begin{array}{c}40.4 \pm 12.3 \\
\quad(34)\end{array}$ & $\begin{array}{l}50.7 \pm 13.2 \\
\quad(554)\end{array}$ & $\begin{array}{c}67.3 \pm 13.5 \\
(24)\end{array}$ \\
\hline $\begin{array}{l}\text { Penpoint gunnel } \\
\text { (Apodichthys flavidus) }\end{array}$ & $\begin{array}{l}22.6 \pm 1.6 \\
(14)\end{array}$ & $\begin{array}{l}25.4 \pm 1.9 \\
(34)\end{array}$ & $\begin{array}{l}25.6 \pm 9.2 \\
(25)\end{array}$ & $\begin{array}{l}28.7 \pm 9.6 \\
\quad(23)\end{array}$ & $\begin{array}{l}38.2 \pm 20.6 \\
(22)\end{array}$ & $\begin{array}{l}25.8 \pm 9.9 \\
\quad(16)\end{array}$ & na \\
\hline $\begin{array}{l}\text { Rosylip sculpin } \\
\text { (Ascelichthys rhodorus) }\end{array}$ & $\begin{array}{l}9.3 \pm 1.9 \\
(14)\end{array}$ & $\begin{array}{l}9.9 \pm 1.5 \\
(8)\end{array}$ & $\begin{array}{l}9.4 \pm 1.6 \\
(16)\end{array}$ & $\begin{array}{l}9.9 \pm 1.9 \\
(13)\end{array}$ & $\begin{array}{l}10.1 \pm 1.3 \\
(12)\end{array}$ & $\begin{array}{c}12.5 \pm 4.2 \\
(6)\end{array}$ & na \\
\hline
\end{tabular}




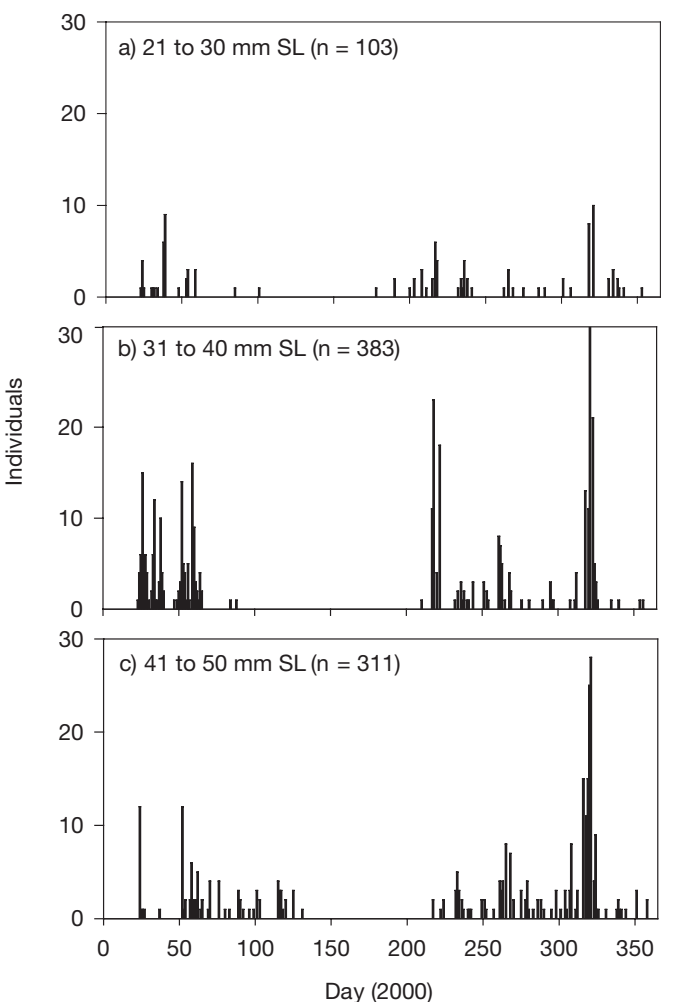

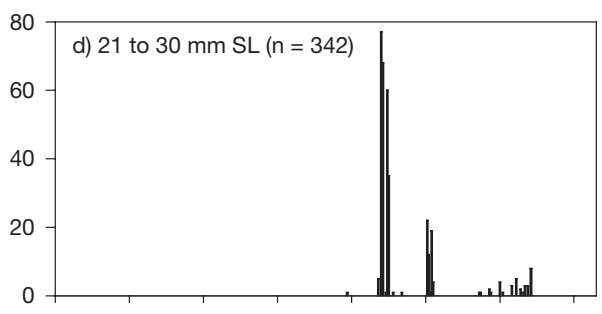
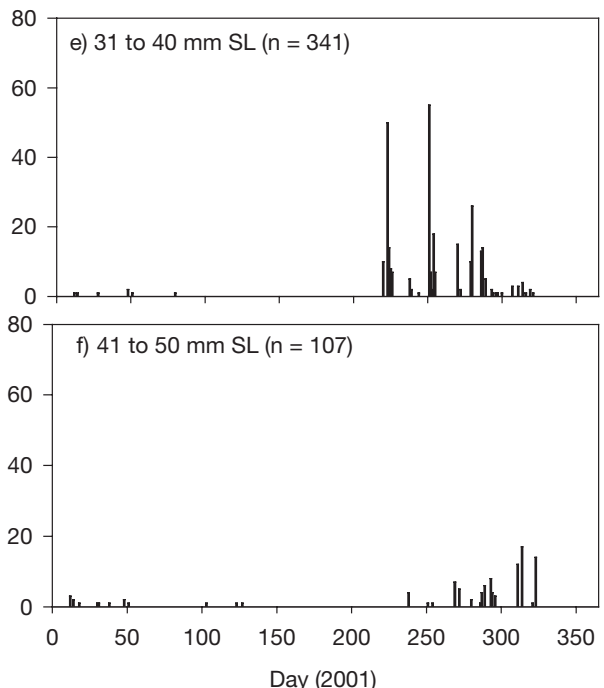

Fig. 5. Engraulis mordax. Daily catch collected at Mid-Slough light traps in 2000 and 2001. SL: standard length
2001 (Table 6). In 1998, significant cross-correlations indicated that peak catches tended to occur between spring and neap tides at the Entrance. At Mid-Slough, significant cross-correlations in catch indicated that peak catches tended to occur during spring tides in 2000 and around neap tides in 2001. Additionally, in 1998, S. sagax abundance was significantly crosscorrelated with positive along-shore (downwelling favorable) wind stress and negative upwelling indices at the Entrance. Similarly, at Mid-Slough in 2000, abundance was significantly cross-correlated with positive along-shore (downwelling favorable) wind stress (Table 6). Time-series analyses were not performed on data from the Entrance in 1999, 2000, and 2001 due to the small number of $S$. sagax collected (i.e. $<50)$.

\section{Surf smelt Hypomesus pretiosus}

The abundance of Hypomesus pretiosus displayed a significant tidal periodicity in catch at both the Entrance and Mid-Slough in 2000 and at Upper Slough in 2001 (Table 6). Significant cross-correlations indicated that catches tended to occur in between spring and neap tides at the Entrance and around spring tides at Mid-Slough in 2000 and around spring tides at Upper Slough in 2001. Additionally, at the Entrance in 2000, H. pretiosus abundance was significantly cross- correlated with positive along-shore (downwelling favorable) wind stress and negative upwelling indices. At Mid-Slough, abundance was cross-correlated with positive cross-shore (shore-ward) wind stress in 2000 and with negative upwelling indices in 2001. Timeseries analyses were not performed on data from the Entrance in 1998 and 1999 due to the small number of H. pretiosus collected (i.e. <50).

\section{Penpoint gunnel Apodichthys flavidus and rosylip sculpin Ascelichthys rhodorus}

There were no significant cross-correlations between the abundance of Apodichthys flavidus or Ascelichthys rhodorus and any of the physical variables examined.

\section{DISCUSSION}

Thirty-five taxa of larval and juvenile fish were collected in Coos Bay light traps over the 3.75 yr study, and 28 were identified to species. Five species, represented primarily by postflexion larvae and juveniles, consistently comprised $>70 \%$ of the total catch. These were northern anchovy Engraulis mordax, penpoint gunnel Apodichthys flavidus, Pacific sardine Sardinops sagax, rosylip sculpin Ascelichthys rhodorus, and surf smelt Hypomesus pretiosus. 

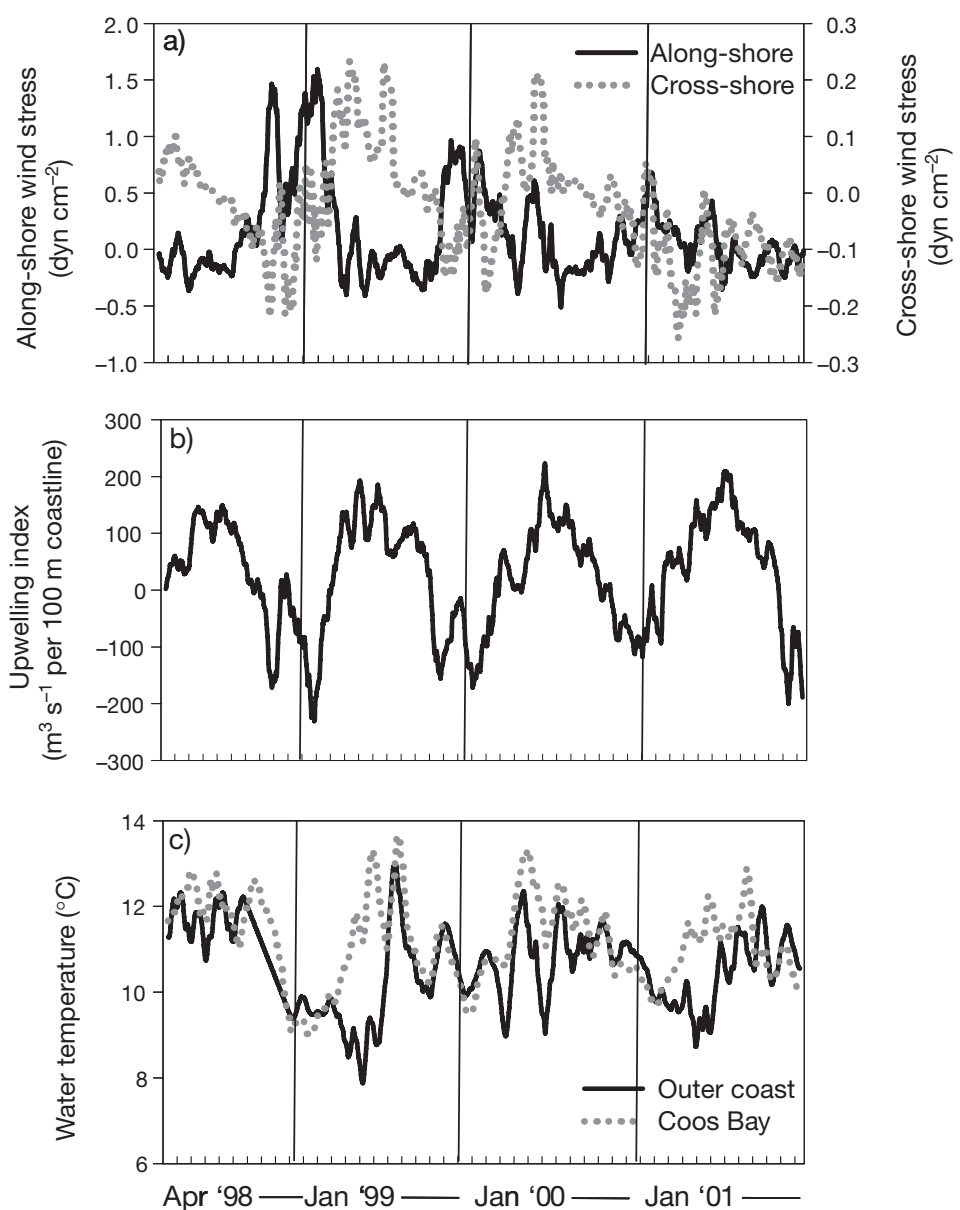

Fig. 6. Time series of physical variables during study. (a) Average daily along-shore and cross-shore wind stress. Positive values are northward (along-shore) and eastward (cross-shore); negative values are southward (along-shore) and westward (cross-shore). Data are from NOAA's C-MAN Stn CAR03 (43 $20^{\prime} 30^{\prime \prime} \mathrm{N}, 124^{\circ} 22^{\prime} 30^{\prime \prime} \mathrm{W}$ ). (b) Average daily upwelling indices at $45^{\circ} \mathrm{N} 125^{\circ} \mathrm{W}$. (c) Average daily surface $\left(0.6 \mathrm{~m}\right.$ depth) water temperature $\left({ }^{\circ} \mathrm{C}\right)$. Outer coast

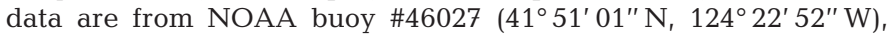
and estuarine data are from NOAA Stn \#9432780 (43 $20^{\prime} 42^{\prime \prime} \mathrm{N}_{\text {, }}$ $\left.124^{\circ} 19^{\prime} 21^{\prime \prime} \mathrm{W}\right)$

Other research in the Pacific Northwest on the use of estuaries by larval and juvenile fish includes surveys that targeted larval and postlarval planktonic (Pearcy \& Myers 1973, Mistano 1977) and benthic fishes (Haertel \& Osterberg 1967, Bottom et al. 1987). Pearcy \& Myers (1973) collected 44 unique types of larval fish and identified 22 to species; the catch was dominated by Pacific herring Clupea harengus pallasi and the bay goby Lepidogobius lepidus. Mistano (1977) collected 22 species of larval, postlarval, and juvenile fish; the catch was dominated by anadromous osmerids (smelts). Haertel \& Osterberg (1967) documented 26 species of fish in the Columbia River estuary; starry flounder Platichthys stellatus and 2 sculpin Cottus asper and Leptocottus armatus comprised the majority of the larval and juvenile catch. Bottom et al. (1987) collected 33 species, including adults and numerous anadromous species, in the Coos Bay South Slough between April and October 1987. Monaco et al. (1992) listed 71 species of fish in Coos Bay. Comparatively, the species richness (27) collected with light traps in Coos Bay is in the range of previous regional studies. The relative species abundances observed in this study, however, are quite different. This was primarily due to the relatively large numbers of Engraulis mordax and Sardinops sagax consistently collected in this study.

\section{Annual patterns}

The majority of fish at the Entrance were collected during downwelling periods, a conclusion similar to other studies in the region (Pearcy \& Myers 1973, Mistano 1977) and one that is consistent with Parrish et al.'s (1981) hypothesis that more species with pelagic larvae would spawn during winter due to more favorable conditions for larval transport. A significant portion (15 to $63 \%$ ) of the total catch, however, occurred during the spring transition (1 April to 31 May). The relative importance of the brief spring transition period may be due, in part, to a correspondence between reproductive and development timing and the end of the downwelling season. Conversely, at Mid-Slough, which was $<1 \mathrm{~km}$ farther up the estuary from the Entrance, a larger proportion of the catch occurred during upwelling with only $8 \%$ collected during the spring transition. This pattern is largely due to relatively large numbers of juvenile Engraulis mordax and Sardinops sagax collected at Mid-Slough during upwelling conditions, which may indicate a preferential use of areas farther up-estuary during upwelling conditions or prolonged residence by some juveniles in that portion of the estuary.

The presence of relatively small Engraulis mordax $(<30 \mathrm{~mm} \mathrm{SL})$ in Coos Bay during late summer through fall supports previous observations that the northern subpopulation spawns in July and August (Richardson 1981). Juvenile E. mordax were collected until the end of 2000 and into November 2001. In 2001, younger fish (21 to $30 \mathrm{~mm}$ SL) were collected in mid-January and were present throughout most of the year. Given the reported spawning times for the northern subpopulation, it is unlikely that these early juveniles came from that subpopulation. They may have come from more southerly locations, i.e. the central subpopulation, where more protracted spawning occurs (Richardson 
Table 6. Engraulis mordax, Sardinops sagax, and Hypomesus pretiosus. Cross-correlations (lags: $\mathrm{r}$ value at that lag) between abundance of the 3 species at Coos Bay light trap locations and physical variables. Lags in days; peaks in species occurred $(+)$ before or $(-)$ after changes in physical variable. Only statistically significant $(p \leq 0.05)$ cross-correlations are presented. ns: no statistical significance; na: insufficient data for analysis. Collection location and year are included

\begin{tabular}{|c|c|c|c|c|}
\hline & $\begin{array}{l}\text { Along-shore } \\
\text { wind stress }\end{array}$ & $\begin{array}{l}\text { Cross-shore } \\
\text { wind stress }\end{array}$ & Upwelling index & Maximum tidal range \\
\hline \multicolumn{5}{|c|}{ Northern anchovy (Engraulis mordax) } \\
\hline \multicolumn{5}{|c|}{ Entrance } \\
\hline 1998 & $-2 \mathrm{~d}:+0.170$ & ns & $-3 \mathrm{~d}:-0.159$ & ns \\
\hline 1999 & na & na & na & na \\
\hline 2000 & ns & $\mathrm{ns}$ & $-6 \mathrm{~d}:-0.146,-7 \mathrm{~d}:-0.203$ & $\begin{array}{l}+4 \mathrm{~d}:-0.210,+5 \mathrm{~d}:-0.234 \\
-2 \mathrm{~d}:+0.234,-3 \mathrm{~d}:+0.236\end{array}$ \\
\hline 2001 & na & na & na & na \\
\hline \multicolumn{5}{|l|}{ Mid-Slough } \\
\hline 2000 & ns & ns & ns & $\begin{array}{l}+4 \mathrm{~d}:-0.205,+5 \mathrm{~d}:-0.248 \\
-1 \mathrm{~d}:+0.207,-2 \mathrm{~d}:+0.217\end{array}$ \\
\hline 2001 & ns & ns & ns & $\begin{array}{l}+1 \mathrm{~d}:-0.323,+2 \mathrm{~d}:-0.394 \\
-3 \mathrm{~d}:+0.235,-4 \mathrm{~d}:+0.332\end{array}$ \\
\hline \multicolumn{5}{|l|}{ Upper Slough } \\
\hline 2001 & ns & $\mathrm{ns}$ & ns & $\begin{array}{l}+0 \mathrm{~d}:-0.389,+2 \mathrm{~d}:-0.411 \\
-4 \mathrm{~d}:+0.355,-6 \mathrm{~d}:+0.450\end{array}$ \\
\hline \multicolumn{5}{|c|}{ Pacific sardine (Sardinops sagax) } \\
\hline \multicolumn{5}{|c|}{ Entrance } \\
\hline 1998 & $-1 \mathrm{~d}:+0.155$ & ns & $-1 \mathrm{~d}:-0.178,-2 \mathrm{~d}:-0.184$ & $\begin{array}{l}+2 \mathrm{~d}:-0.243,+3 \mathrm{~d}:-0.293 \\
-4 \mathrm{~d}:+0.170,-5 \mathrm{~d}:+0.199\end{array}$ \\
\hline 1999 & na & na & na & na \\
\hline 2000 & na & na & na & na \\
\hline 2001 & na & na & na & na \\
\hline \multicolumn{5}{|l|}{ Mid-Slough } \\
\hline 2000 & $\begin{array}{l}-3 \mathrm{~d}:+0.137 \\
-4 \mathrm{~d}:+0.152\end{array}$ & ns & ns & $+0 \mathrm{~d}:+0.160,-1 \mathrm{~d}:+0.159$ \\
\hline 2001 & ns & $\mathrm{ns}$ & ns & $\begin{array}{l}+0 \mathrm{~d}:-0.142,+1 \mathrm{~d}:-0.155 \\
+7 \mathrm{~d}:+0.202,+8 \mathrm{~d}:-0.198\end{array}$ \\
\hline \multicolumn{5}{|c|}{ Surf smelt (Hypomesus pretiosus) } \\
\hline \multicolumn{5}{|c|}{ Entrance } \\
\hline 1998 & na & na & na & na \\
\hline 1999 & na & na & na & na \\
\hline 2000 & $-5 \mathrm{~d}:+0.149$ & ns & $-6 \mathrm{~d}:-0.205,-7 \mathrm{~d}:-0.202$ & $-3 \mathrm{~d}:+0.170,-4 \mathrm{~d}:+0.160$ \\
\hline 2001 & ns & ns & ns & ns \\
\hline \multicolumn{5}{|l|}{ Mid-Slough } \\
\hline 2000 & ns & $\begin{array}{l}+0 \mathrm{~d}:+0.173 \\
-1 \mathrm{~d}:+0.203\end{array}$ & ns & $+0 \mathrm{~d}:+0.210,-1 \mathrm{~d}:+0.190$ \\
\hline 2001 & ns & ns & $-6 \mathrm{~d}:-0.140,-7 \mathrm{~d}:-0.174$ & ns \\
\hline \multicolumn{5}{|l|}{ Upper Slough } \\
\hline 2001 & ns & ns & ns & $-8 \mathrm{~d}:-0.341$ \\
\hline
\end{tabular}

1981). During winter months the Davidson Current (Inshore Counter Current), which is the predominant along-shore flow nearshore in Oregon, flows northward. Therefore, transport toward Coos Bay from more southerly locations is possible. If this is the case, these 2 subpopulations overlap geographically in their use of Coos Bay. Their residence, however, appears to be distinctly separated in time.

\section{Interannual abundance}

In 1999, the catch of the winter spawners Apodichthys flavidus, Ascelichthys rhodorus, and the Sebastes spp. was relatively large, and the catch of En- graulis mordax and Sardinops sagax, which have more protracted spawning periods that typically begin later in the year, was relatively small compared with the other 2 years of data. Although 1999 is characterized as a strong La Niña year, the lack of any significant crosscorrelations between catch and the physical variables examined makes it difficult to determine if the observed interannual variation in species abundance reflects actual differences in abundance or possibly different transport and/or movement patterns. One notable difference is that the mean and variance of the along-shore wind stress for the first $100 \mathrm{~d}$ of the year were greater in $1999\left(0.84 \pm 1.4 \mathrm{dyn}^{-2}\right)$ than the other years (average $=0.28 \pm 0.50$ dyn $\mathrm{cm}^{-2}$ ). Greater wind stress during winter potentially resulted in 
enhanced downwelling that could have contributed to enhanced estuarine ingress and/or retention of the winter spawned larvae. It is unclear, however, why E. mordax and S. sagax catches were lower.

\section{Relative abundance and size}

The catch of Engraulis mordax, Sardinops sagax, Hypomesus pretiosus, and Apodichthys flavidus at trap locations farther up the estuary was significantly and positively cross-correlated, with catch lower in the estuary, suggesting that individuals moved up the estuary shortly after arrival at the Entrance site. In 2000 and 2001, however, peaks in the catch of S. sagax at sample locations farther up-estuary also occurred $1 \mathrm{~d}$ prior to peaks lower in the estuary. This may indicate a preferential use of areas farther up the estuary. Alternatively, some juvenile $S$. sagax may remain in the South Slough arm of Coos Bay for extended periods. If this were the case, however, one would expect their average size to increase and observed sizes were similar at both locations in 2000 and 2001.

Generally, the annual average daily fish size was similar between and among sites for the dominant species collected. In some cases, larger fish were collected farther up estuary, i.e. Apodichthys flavidus in 2000 and Hypomesus pretiosus in 2000 and 2001. These data suggest that, at least for some species, individuals moved up-estuary after their initial entrance. The occurrence of larger individuals farther up estuary may be due to higher growth rates, enhanced tidal-stream transport by older juveniles with enhanced swimming ability, the ingress of smaller individuals into the estuary, or a combination of such factors (Laprise \& Dodson 1989, Kimura et al. 2000, Forward \& Tankersley 2001).

\section{Transport and estuarine ingress}

Although the catch data indicate larvae and juveniles were more abundant in the estuary during the downwelling season, there was minimal evidence for downwelling-related transport. For example, there were no significant cross-correlations between indicators of downwelling events and the abundance of Apodichthys flavidus or Ascelichthys rhodorus and infrequent, relatively weak cross-correlations for Engraulis mordax, Sardinops sagax, and Hypomesus pretiosus. There was no evidence for upwelling-related transport. Significant cross-correlations between species abundance and the spring-neap tidal cycle were more consistent.

At times, the relationship between catch and tidal stage was consistent among species. At Mid-Slough in 2000, for example, peaks in all 3 species were associ- ated with spring tides. Similarly, at the Entrance in 2000, peaks in the abundance of Engraulis mordax and Hypomesus pretiosus were associated with spring tides. This may occur, in part, via selective tidal-stream transport (STST). Numerous studies have documented STST in estuaries (Laprise \& Dodson 1989, Kimura et al. 2000, Forward \& Tankersley 2001), and modeling efforts have demonstrated that net horizontal displacement of zooplankton may occur in the presence of oscillatory tidal currents and diel vertical migrations (Hill 1998). Another potential mechanism of shoreward transport is non-linear internal tides and bores. Increased concentrations of larval fish and invertebrates (Shanks 1983, 1998, Pineda 1991), juvenile fish (Kingsford \& Choat 1986), and small adult fish (Rogachev et al. 1996) have been observed in slicks associated with internal waves and bores. In some cases, the shoreward transport of material concentrated in slicks associated with internal waves was observed directly (Shanks 1983, 1988) or tidal frequencies in the nearshore abundance of larval invertebrates and fish were identified (Shanks 1983, Pineda 1991, 1994, Shanks 1998). Therefore, it is possible that a combination of STST and non-linear internal tides and bores contributed to the abundance patterns observed in this study. Overall, these data indicate that the presence of larval and juvenile fish within Coos Bay may have been regulated more by tidally-driven, rather than wind-driven, transport.

Although we only considered larval and juvenile fish collected in light traps in the lower estuary, we can make some regional comparisons. In a comprehensive review of estuarine salt marsh fishes, Nordlie (2003) found marine transients to comprise the largest component of fish collected in estuaries $(52.3 \%)$, followed by marine nursery $(17.7 \%)$, freshwater transients $(15.2 \%)$, permanent residents $(9.3 \%)$, and diadromous fishes $(5.5 \%)$. Similarly, marine transients and marine nursery species comprised the 2 largest fractions of fish collected in South African estuaries (Nordlie 2003). Of the 28 species identified in this study, 3 are marine species that are known to use estuaries as nursery areas: topmelt Atherinops affinis, staghorn sculpin Leptocottus armatus, and English sole Parophrys vetulus (Bottom et al. 1987). This does not necessarily mean these species are estuarine dependent, although there is such evidence for $P$. vetulus (Boehlert \& Mundy 1987), but they can be considered to use the estuary as a nursery. Additionally, although not technically estuarine dependent and considered here to be a marine transient, the tube snout Aulorhynchus flavidus may very well function as a permanent estuarine resident. Thus, $88.5 \%$ of the species collected in this study can be considered marine transient with the remaining $11.5 \%$ as marine nursery. No freshwater transients or diadro- 
mous species were collected in this study. Furthermore, Nordlie (2003) reported that Engraulidae and Clupeidae are among the most widely distributed families found in estuaries. There were 3 representatives of these families collected in this study: 1 from Engraulidae and 2 from Clupeidae.

The potential nursery function of Coos Bay is difficult to determine without additional information from areas outside of the estuary. In 2000, simultaneous collections of Engraulis mordax were made at an outer coastal and estuarine site (Miller \& Shanks 2004). In that case, significantly more E. mordax were collected at the outer coast compared to the estuary. In the current study, however, relatively large numbers of larval Apodichthys flavidus and Ascelichthys rhodorus were present in Coos Bay for 2 to 3 mo while juvenile $E$. mordax and Hypomesus pretiosus were often present throughout much of the year. It would be premature to conclude that Coos Bay does not provide nursery areas for some of these species without additional information on growth and survival.

We conclude, as did Doherty (1987), that light traps are selective but useful devices for determining the distribution and relative abundance of larval and juvenile fishes. These results further support the utility of light traps in temperate estuaries (Hickford \& Schiel 1999, Strydom 2003, Miller \& Shanks 2004). The relative abundance patterns we observed indicate seasonal and spatial variation in estuarine use and potentially extended residence periods for some species. Certain species-Apodichthys flavidus, Ascelichthys rhodorus, and Engraulis mordax - were collected at small sizes $(10,26$, and $\leq 30 \mathrm{~mm}$, respectively) in discrete pulses that were temporally coherent among years. Additionally, there were numerous indications of shoreward transport and/or estuarine ingress through tidally-driven transport processes but less support for wind-driven transport. Overall, the evidence presented here indicates that the presence of the larval and juvenile fish collected within Coos Bay may have been primarily regulated by a combination of tidally-driven transport and reproductive timing.

Acknowledgements. Field assistance was provided by E. Backus, A. McCulloch, A. Puls, K. Zosel, J. Tyson, J. April, and D. Williams. Valuable suggestions and encouragement were generously supplied by C. Roegner. We appreciate the helpful comments of T. Miller and 2 anonymous reviewers. This research was funded by an ERD, OOCRM, NOS, NOAA grant to J.A.M. and an NSF SGER to A.L.S.

\section{LITERATURE CITED}

Able KW, Fahay MP (1998) The first year in the life of estuarine fishes in the Middle Atlantic Bight. Rutgers University Press, New Brunswick, NJ
Beck MW, Heck KLJ, Able KW, Childers DL and 9 others (2001) The identification, conservation, and management of estuarine and marine nurseries for fish and invertebrates. Bioscience 51:633-641

Boehlert GW, Mundy BC (1987) Recruitment dynamics of metamorphosing English sole, Parophrys vetulus, to Yaquina Bay, Oregon. Estuar Coast Shelf Sci 25:261-281

Boehlert GW, Mundy BC (1988) Roles of behavioral and physical factors in larval and juvenile fish recruitment to estuarine nursery areas. Am Fish Soc Symp 3:51-67

Bottom DL, Jones KK, Rodgers JD (1987) Fish community structure, standing crop, and production in upper Sough Slough (Coos Bay), Oregon. NOAA Tech Rep No SOS 1-88, Portland

Cury P, Roy C (1989) Optimal environmental window and pelagic fish recruitment success in upwelling areas. Can J Fish Aquat Sci 46:670-680

Doherty PJ (1987) Light-traps: selective but useful devices for quantifying the distributions and abundances of larval fishes. Bull Mar Sci 41:423-431

Elliott M, Hemingway KL (2002) Fishes in estuaries. Blackwell, London

Emery WJ, Thomson RE (1997) Data analysis methods in physical oceanography. Pergamon, Oxford

Epifanio CE, Garvine RW (2001) Larval transport on the Atlantic continental shelf of North America: a review. Estuar Coast Shelf Sci 52:51-77

Fisher JP, Pearcy WG (1990) Distribution and residence times of juvenile fall and spring chinook salmon in Coos Bay, Oregon. Fish Bull (Wash DC) 88:51-58

Forward RB, Tankersley RA (2001) Selective tidal-stream transport of marine animals. Oceanogr Mar Biol Annu Rev 39:305-353

Goodrich DM, van Montfrans J, Orth RJ (1989) Blue crab megalopal influx to Chesapeake Bay: evidence for a winddriven mechanism. Estuar Coast Shelf Sci 29:247-260

Haedrich RL (1983) Estuarine fishes. In: Ketchum BH (ed) Ecosystems of the world 26, Estuaries and enclosed seas. Elsevier, New York, p 187-207

Haertel L, Osterberg C (1967) Ecology of zooplankton, benthos and fishes in the Columbia River estuary. Ecology 48: $459-472$

Healey MC (1982) Juvenile Pacific salmon in estuaries: the life support system. In: Kennedy VS (ed) Estuarine comparisons. Academic Press, New York, p 315-341

Hickford MJH, Schiel DR (1999) Evaluation of the performance of light traps for sampling fish larvae in inshore temperate waters. Mar Ecol Prog Ser 186:293-302

Hill AE (1998) Diel vertical migration in stratified tidal flows: implications for plankton dispersal. J Mar Res 56: 1069-1096

Huyer A, Sobey EJC, Smith RL (1979) The spring transition in currents over the Oregon continental shelf. J Geophys Res C 84:6995-7011

Kimura R, Secor DH, Houde ED, Piccoli PM (2000) Up-estuary dispersal of young-of-the-year bay anchovy Anchoa mitchilli in the Chesapeake Bay: inferences from microprobe analysis of strontium in otoliths. Mar Ecol Prog Ser 208:217-227

Kingsford M, Choat JH (1986) The influence of surface slicks on the distribution and onshore movement of small fish. Mar Biol 91:161-171

Kucas ST Jr (1986) Species profiles: life histories and environmental requirements of coastal fishes and invertebrates (Pacific southwest) - northern anchovy. U.S. Fish Wildl Serv Biol Rep 82

Laprise R, Dodson JJ (1989) Ontogeny and importance of tidal 
vertical migrations in the retention of larval smelt Osmerus mordax in a well-mixed estuary. Mar Ecol Prog Ser 55:101-111

Lasker R (1974) Field criteria for survival of anchovy larvae: the relation between inshore chlorophyll maximum layers and successful first feeding. Fish Bull US 73:453-462

Love MS (1996) Probably more than you want to know about the fishes of the Pacific Coast. Really Big Press, Santa Barbara, California

Milicich MJ, Doherty PJ (1994) Larval supply of coral reef fish populations: magnitude and synchrony of replenishment to Lizard Island, Great Barrier Reef. Mar Ecol Prog Ser 110:121-134

Miller BA, Sadro S (2003) Residence time and seasonal movements of juvenile coho salmon in the ecotone and lower estuary of Winchester Creek, South Slough, Oregon. Trans Am Fish Soc 132:546-559

Miller JA, Shanks AL (2004) Ocean-estuary coupling in the Oregon upwelling region: abundance and transport of juvenile fish and of crab megalopae. Mar Ecol Prog Ser 271:267-279

Mistano DA (1977) Species composition and relative abundance of larval and post-larval fishes in the Columbia River estuary, 1973. Fish Bull (Wash DC) 75:218-222

Monaco ME, Lowery TA, Emmett RL (1992) Assemblages of the U.S. west coast estuaries based on the distribution of fishes. J Biogeogr 19:251-267

Mooers CNK, Collins CA, Smith RL (1976) The dynamic structure of the frontal zone in the coastal upwelling region off Oregon. J Phys Oceanogr 6:3-21

Munch SB, Conover DO (2000) Recruitment dynamics of bluefish (Pomotomus saltatrix) from Cape Hatteras to Cape Cod. ICES J Mar Res 57:393-402

Nordlie FG (2003) Fish communities of estuarine salt marshes of eastern North America, and comparisons with temperate estuaries of other continents. Rev Fish Biol Fish 13: 281-325

Parrish RH, Nelson CS, Bakun A (1981) Transport mechanisms and reproductive success of fishes in the California Current. Biol Oceanogr 1:175-203

Pearcy WG, Myers SS (1973) Larval fishes of Yaquina Bay, Oregon: a nursery ground for marine fishes? Fish Bull (Wash DC) 72:201-213

Peterman RM, Bradford MJ, Lo NCH, Methot RD (1988) Contribution of early life stages to interannual variability in recruitment of northern anchovy (Engraulis mordax). Can J Fish Aquat Sci 45:8-16

Petersen CW, Zarrella KA, Ruben CA, Mazzoldi C (2004)

Editorial responsibility: Otto Kinne (Editor-in-Chief), Oldendorf/Luhe, Germany
Reproductive biology of the rosylip sculpin, an intertidal spawner. J Fish Biol 64:868-875

Pineda J (1991) Predictable upwelling and the shoreward transport of planktonic larvae by internal tidal bores. Science 253:548-551

Pineda J (1994) Internal tidal bores in the nearshore: warmwater fronts, seaward gravity currents and the onshore transport of neustonic larvae. J Mar Res 52:427-458

Richardson SL (1981) Spawning biomass and early life history of northern anchovy, Engraulis mordax, in the northern subpopulation off Oregon and Washington. Fish Bull (Wash DC) 78:855-876

Roegner GC, Shanks AL (2001) Import of coastally-derived chlorophyll a to South Slough, Oregon. Estuaries 24: $244-256$

Roegner GC, Hickey BM, Newton JA, Shanks AL, Armstrong DA (2002) Wind-induced plume and bloom intrusions into Willapa Bay, Washington. Limnol Oceanogr 47:1033-1042

Rogachev KA, Salomatin AS, Carmack EC (1996) Concentration of pelagic organisms at mesoscale fronts in the western subarctic Pacific: small fish on long waves. Fish Oceanogr 5:153-162

Shanks AL (1983) Surface slicks associated with tidally forced internal waves may transport pelagic larvae of benthic invertebrates and fishes shoreward. Mar Ecol Prog Ser 13: 311-315

Shanks AL (1988) Further support for the hypothesis that internal waves can cause shoreward transport of larval invertebrates and fish. Fish Bull (Wash DC) 86:703-714

Shanks AL (1995) Mechanisms of cross-shelf dispersal of larval invertebrates and fish. In: McEdward L (ed) Ecology of marine invertebrate larvae. CRC Press, New York, p 323-367

Shanks AL (1998) Abundance of post-larval Callinectes sapidus, Penaeus spp., Uca spp., and Libinia spp. collected at an outer coastal site and their cross-shelf transport. Mar Ecol Prog Ser 168:57-69

Strub PT, Allen JS, Huyer A, Smith RL (1987) Seasonal cycles of currents, temperatures, winds, and sea level over the northeast Pacific continental shelf: $35^{\circ} \mathrm{N}$ to $48^{\circ} \mathrm{N}$. J Geophys Res 92:1507-1526

Strub PT, James C (2000) Altimeter-derived variability of surface velocities in the California Current System: 2. Seasonal circulation and eddy statistics. Deep-Sea Res II 47: 831-870

Strydom NA (2003) An assessment of habitat use by larval fishes in a warm temperate estuarine creek using light traps. Estuaries 26:1310-1318

Submitted: November 2, 2004; Accepted: July 15, 2005

Proofs received from author(s): November 22, 2005 